University of Nebraska - Lincoln

DigitalCommons@University of Nebraska - Lincoln

USDA National Wildlife Research Center - Staff Publications
U.S. Department of Agriculture: Animal and Plant Health Inspection Service

1999

\title{
Repellents to Reduce Cable Gnawing by Northern Pocket Gophers
}

Stephen A. Shumake

USDA-APHIS-Wildlife Services

Ray T. Sterner

USDA-APHIS-Wildlife Services

Stanley E. Gaddis

USDA-APHIS-Wildlife Services

Follow this and additional works at: https://digitalcommons.unl.edu/icwdm_usdanwrc

Part of the Environmental Sciences Commons

Shumake, Stephen A.; Sterner, Ray T.; and Gaddis, Stanley E., "Repellents to Reduce Cable Gnawing by Northern Pocket Gophers" (1999). USDA National Wildlife Research Center - Staff Publications. 855. https://digitalcommons.unl.edu/icwdm_usdanwrc/855

This Article is brought to you for free and open access by the U.S. Department of Agriculture: Animal and Plant Health Inspection Service at DigitalCommons@University of Nebraska - Lincoln. It has been accepted for inclusion in USDA National Wildlife Research Center - Staff Publications by an authorized administrator of DigitalCommons@University of Nebraska - Lincoln. 


\title{
REPELLENTS TO REDUCE CABLE GNAWING BY NORTHERN POCKET GOPHERS
}

STEPHEN A. SHUMAKE,' U.S. Department of Agriculture, Animal and Plant Health Inspection Service, National Wildife Research Center, Fort Collins, CO 80521, USA

RAY T. STERNER, U.S. Department of Agriculture, Animal and Plant Health Inspection Service, National Wildlife Research Center, Fort Collins, CO 80521, USA

STANLEY E. GADDIS, U.S. Department of Agriculture, Animal and Plant Health Inspection Service, National Wildlife Research Center, Fort Collins, CO 80521, USA

\begin{abstract}
There is a continuing need to develop improved repellent formulations to protect buried cable installations from damage by problem wildlife. We evaluated $2.0 \%$ mass/mass levels of capsaicin and denatonium benzoate in a polybutene carrier material (Indopo ${ }^{(i)}$ ) and an aboveground, rodent-deer plastic mesh barrier (Vexar $\left.{ }^{\circledR}\right)$ for reducing gnawing by northern pocket gophers (Thomomys talpoides) on communications cable (RG-8U). When treatments were applied as surface coatings, neither capsaicin nor denatonium samples were lower $(P>0.05)$ in measures of cable damage compared to control (Indopol ${ }^{\circledR}$ alone) or samples treated with $\operatorname{Vexar}^{\circledR}$ plastic mesh. When the test was repeated with a new group of 24 gophers $(n=6 /$ group in each of 4 groups) but with the $2.0 \%$ capsaicin, $2.0 \%$ denatonium benzoate, and Indopol ${ }^{\mathbb{E}}$ enclosed with electrical shrink tubing, there was less damage for the capsaicin samples $(P<0.05)$ on mass, depth of cut, width, and volume of cable chewed when compared to samples treated with the Vexar ${ }^{\circledR}$ and Indopol ${ }^{\circledR}$. Denatonium benzoate treatment also produced repellent effects $(P<0.05)$ on the width measure when compared to Vexar samples. In addition, the denatonium benzoate samples were damaged less than Indopol ${ }^{\circledR}$ samples, although not significantly, as measured by mass loss and depth of gnawing. Therefore, we concluded that although capsaicin and denatoneum benzoate appeared to be completely ineffective when applied as a surface coating to cable, the same agents became effective cable gnawing repellents when encased in electrical shrink tubing. This encasing procedure demonstrated quite clearly that the means for applying the repellent agent are an all important aspect of developing effective products to control gnawing damage by northern pocket gophers.
\end{abstract}

JOURNAL OF WILDLIFE MANAGEMENT 63(4):1344-1349

Key words: cable damage, gnawing, pocket gopher, repellent, Thomomys talpoides.

Northern pocket gophers and plains pocket gophers (Geomys bursarius) cause extensive damage to buried communications cables, power lines, and irrigation hosing. Previous attempts to repel gophers from gnawing have involved physical barriers (Connolly and Cogelia 1970, Cogelia et al. 1976) or chemical repellents (Howard 1953, Connolly and Landstrom 1969, McCann 1995). An extensive history (1966-95) of cable repellent research to reduce damage by pocket gophers is covered in detail by Ramey and McCann (1997). However, despite a great deal of empirical screening for improved, longlasting repellents, few reports outline agents with the potential for commercial development. A main reason for this lack of scientific documentation stems from the proprietary nature of past testing programs. Most of the previous work was conducted under contract with private cable manufacturers under confidentiality

\footnotetext{
${ }^{1}$ E-mail: stephen.a.shumake@usda.gov
}

agreements that precluded publication or disclosure of results (Ramey and McCann 1997).

More recently, some basic research on olfactory predator avoidance by gophers (Sullivan et al. 1988) and on trigeminal nerve irritants to reduce feeding by gophers has been conducted (Epple et al. 1996), but no attempts were made to apply the repellent agents to underground cables. An extremely bitter-tasting compound, denatonium benzoate, was applied as a foliar spray or systemically at $2.0 \%$ concentration to reduce damage by northern pocket gophers (hereafter, gophers) to conifer seedlings in Oregon and Idaho, but no indications of reduced damage were found (Witmer et al. 1998). Other reports (Bryant 1997, Mason 1998) have indicated that the bitter-tasting repellents do not consistently repel herbivores. However, Fitzgerald et al. (1997) have demonstrated efficacy of capsaicin as a seed treatment repellent for gray squirrels (Sciurus carolinensis). A microencapsulated capsaicin formulation for use as a rodent repellent was developed in Japan 
(Japanese patents $93193910 \mathrm{~A} 2$ and 05139910), but to our knowledge the degree of gopher repellent efficacy for this product remains unpublished. Our approach has been to take a closer examination of traditional repellents such as capsaicin (i.e., the active ingredient in hot pepper flavor agents), bittering agents (e.g., denatonium benzoate), and a mechanical, commercially available barrier (i.e., Vexar ${ }^{\circledR}$ plastic mesh) and to attempt demonstrations of repellent efficacy with an improved means of chemical delivery.

\section{METHODS}

\section{Animals}

We trapped gophers $(n=72)$ by using Mason jar traps with hinged-weighted lids near Wellington, Colorado, under Colorado State licenses (96-0621, 97-0621). Prior to use in experiments, all animals were kept under quarantine for 14 days at the National Wildlife Research Center Animal Research Building, Fort Collins, Colorado. Animals were maintained throughout testing on a diet of carrot and Purina Rodent Biscuits and water. Colony and test-room temperatures were kept within defined limits (20$25^{\circ} \mathrm{C}$ ), but humidity levels were uncontrolled and generally were $<30 \%$ relative humidity. Room lights throughout quarantine and testing were kept off except for $2 \mathrm{hr} /$ day for animal maintenance and treatment setup.

\section{Cable Samples and Chemicals}

Lengths of coaxial communications cable (RG-8U) obtained from a local vendor were cleaned with $10 \%$ laboratory ethanol to remove possible residues left from extrusion processing, rinsed with deionized water, and dried with clean paper towels. The cable was cut into 10cm lengths for use in tests.

Capsaicin oleoresin in red liquid form (CAS 8023-77-6) was purchased as a I-L sample (Lot 46051) from Penta Manufacturing (Livingston, New Jersey, USA). Denatonium benzoate in white crystalline form (CAS 3734-33-6) was purchased as a 5-g sample (Lot 54H0218) from Sigma Chemical (St. Louis, Missouri, USA). Indopol ${ }^{\circledR}$ H-1900 polybutene clear liquid base material (CAS 9003-29-6) was obtained as a IL sample (Lot U95A95U1) from Amoco Chemical (Naperville, Illinois, USA). Vexar seedling protector plastic mesh tubes were obtained from Terra Tech (Eugene, Oregon, USA).

\section{Study 1: Surface Coat}

From the initial group of 30 gophers screened for cable gnawing, we selected 21 for repellent tests. Animals were housed in individual stainless steel wire-mesh cages $(33.6 \times 17.8$ $\times 17.8 \mathrm{~cm})$. Each cage was partitioned by a $17-$ $\times 17-\mathrm{cm}$ stainless steel plate that prevented animal access to approximately one-third of the cage. In the center of each steel plate, at a height of $2.5 \mathrm{~cm}$ above the cage floor, a centered 5- $\times 5-\mathrm{cm}$ square opening was blocked by a $10-\mathrm{cm}$ horizontal length of $1.2-\mathrm{cm}$-diameter RG-8 coaxial cable attached to the sides of the plate with 18-guage steel tying wire. Food and carrot (as a moisture source) were provided to each animal throughout the 7-day exposure screening. Each day at $0800 \mathrm{MST}$, the degree of cable damage on each sample was assessed and recorded according to a previously described scale (McCann 1995). The scale assigned a value of (1) for no damage observed, (2) for incisor teeth marks on the sample, (3) for chewing by gophers where the outer cable covering had been penetrated, (4) for chewing in which the inner conductor cable wires had been gnawed, and (5) for cable samples that had been completely gnawed through. At the end of the 7-day interval, all samples were placed in individual plastic bags and labeled according to date and animal tested.

Further measures on the cable samples included (1) mass loss as determined by the difference between pre- and postexposure mass (nearest $0.01 \mathrm{~g}$ ) as measured with a Mettler (Model PM2000) top-loading balance, (2) volume loss as determined by water displacement (nearest $0.1 \mathrm{cc}$ ) in a $10-\mathrm{cc}$ graduated cylinder with comparisons made between gopher-exposed and unexposed lengths of RG-8 cable, (3) total penetration width as measured (nearest $0.01 \mathrm{~mm}$ ) with a digital caliper (Mitutoyo No. 2081), (4) total penetration depth measured (nearest $0.01 \mathrm{~mm}$ ) with this same instrument, and, (5) the 1-5 qualitative damage ranking described"above for the final exposure day.

All 21 animals selected for Study 1 had shown at least a Level 3 damage after 3 days of cable exposure in their home cages. Animals were divided by random selection into 3 groups $(n=$ $6 /$ treatment) and 1 placebo (Indopol ${ }^{\star}$ carrier) group $(n=3)$. Sex was not found to be a significant factor in gnawing propensities of this species and was therefore also randomized 
across groups. The capsaicin and denatonium benzoate treatments were made up with a $2.0 \%$ mass/mass level of the ingredient added to a mixture of $80 \%$ Indopol ${ }^{\circledR}$ plus $20 \%$ mineral oil. The control-placebo treatment consisted of this later mixture without the addition of other ingredients. Each of the 3 treatment materials was made up $24 \mathrm{hr}$ in advance of testing and stored separately at room temperature. Each treatment substance was applied topically to the $10-\mathrm{cm}$ cable samples with $2.54-\mathrm{cm}$ disposable sponge-rubber painting tools and then attached to individual test panels. Vexar ${ }^{\$}$ plastic mesh material was cut to size to wrap around each sample $(10 \times 7 \mathrm{~cm})$ and attached to the sample and panel with tying wire.

\section{Study 2: Shrink Tubing Encasement}

In Study 2, we attempted to increase mucosal and facial contact with the repellents as the gophers gnawed on the cable samples. From the remaining 42 pocket gophers showing Level 3 or greater gnawing activity during screening trials, 24 animals were randomly selected to receive the same treatments listed for the topical coat treatments (i.e., capsaicin, denatonium benzoate, Indopol ${ }^{\circledast}$, Vexar ${ }^{\circledast}$ mesh), but with the first 3 treatments contained as 2.0 cc of total volume within a length of $1.27-\mathrm{cm}$ plastic shrink-tubing obtained from a local electronics supply store. Shrink tubing was cut to $13-\mathrm{cm}$ lengths and placed over individual cable samples. Forced-air heat from a laboratory heat gun (Model HG-301; Master Appliance, Racine, Wisconsin, USA) was used to shrink and seal 1 end of the cable samples. We then added 2.0 cc of the assigned agent to the interstitial area between the cable and the tubing via a $3.0-\mathrm{cc}$ disposable plastic syringe. The remaining end of the tubing was sealed with the heat gun, and the samples were attached to individual stainless steel panels. After random assignment to the 4 treatments ( $n=6 /$ treatment), we allowed all gophers unrestricted exposure to the 10-cm cable samples for 7 days as described for Study 1 . The same measurements were taken on each sample.

\section{Data Analyses}

Study 1 and Study 2 data were analyzed with separate 1-way analyses of variance (ANOVA; Winer 1971), and computations were performed via PROC-GLM-ANOVA and Type 3 sums-of-squares (SAS Institute 1992). Signifi-

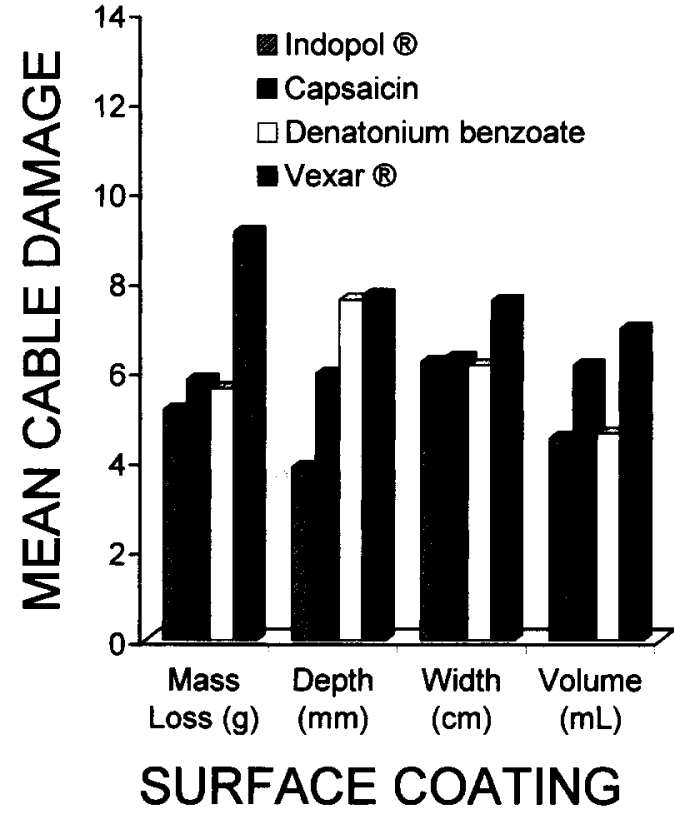

Fig. 1. Northern pocket gopher gnawing damage to cable samples treated with 3 topically applied repellent agents: capsaicin, denatonium benzoate, Vexart plastic mesh, and Indopol $^{*}$ (placebo) after 7 days of exposure to individual animals.

cance of main effects was further assessed via post hoc Student-Newman-Keuls tests to compare mean differences with an alpha level of 0.05 .

\section{RESULTS}

In Study 1, when topical applications were used, no repellent effects were detected on any of the 4 quantitative measures (Fig. 1). The ANOVA results for Study 1 were as follows: mass loss $\left(F_{3,17}=1.48, P=0.225\right)$; depth of gnawing $\left(F_{3,17}=1.42, P=0.271\right)$; width of gnawing $\left(F_{3,17}=0.72, P=0.556\right)$; and volume of gnawing $\left(F_{3,17}=0.64, P=0.600\right)$. Final qualitative damage ratings were compared with descriptive statistics only because there were many tied scores, which limited inferences that could made when applying any nonparametric tests of significance. Mean \pm standard deviation values for the 4 groups were $2.00 \pm 1.41$ (Indopol ${ }^{\circledR}$ ), $3.41 \pm 1.24$ (capsaicin), $3.83 \pm 0.90$ (denatonium benzoate), and $3.83 \pm 0.69$ (Vexar $\left.{ }^{\circledast}\right)$.

In Study 2, when plastic shrink tubing was used to maintain a high volume of chemical repellent surrounding the cable samples, effects were detected for capsaicin and denatonium benzoate samples (Fig. 2). Capsaicin exhibited the highest level of repellency. Denatonium 


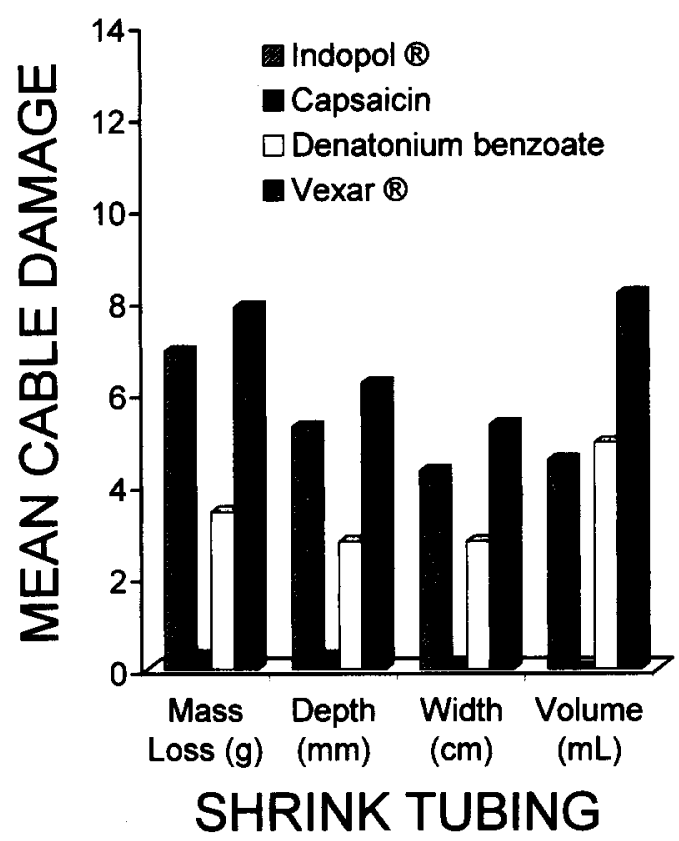

Fig. 2. Northern pocket gopher gnawing damage to cable samples treated with 2 chemical repellents: capsaicin, denatonium benzoate, and Indopol ${ }^{\odot}$ (placebo) encased in electrical shrink tubing. Vexar plastic mesh was used as a mechanical repellent surrounding the samples.

benzoate showed a lesser degree of repellency compared to capsaicin and the other 2 treatments.

The ANOVA results for the mass loss measure in Study 2 were significant $\left(F_{3,20}=5.45, P\right.$ $=0.007$ ). Student-Newman-Keuls tests indicated that capsaicin samples showed less mean mass loss compared to the means for Indopol ${ }^{\circledR}$ and Vexar ${ }^{\circledR}$ samples. The means for denatonium benzoate and capsaicin were not different. Levels of damage reduction represented by mean cable mass loss due to gnawing were $95.6 \%$ for capsaicin and $50.5 \%$ for denatonium benzoate when compared to Indopol ${ }^{\circledR}$.

Results for the depth of gnawing measure were also significant $\left(F_{3,20}=7.07, P=0.002\right)$. Post hoc tests indicated that the mean for capsaicin was lower than means for Indopol ${ }^{\circledR}$, Vexar, and denatonium benzoate. The means for denatonium benzoate and capsaicin were not shown to be different. Levels of damage reduction indicated by mean depth of gnawing were $\mathbf{9 4 . 7 \%}$ for capsaicin and $47.4 \%$ for denatonium benzoate when compared to Indopol ${ }^{\star}$.

For the width of cable damage measure, significant repellent effects $\left(F_{3,20}=11.06, P=\right.$ 0.001 ) were again detected. Post hoc tests in- dicated that the mean for capsaicin was lower than the means for Indopo ${ }^{\oplus}$, Vexar ${ }^{\circledR}$, and denatonium benzoate. The mean for denatonium was lower than the mean for Vexar ${ }^{\circledR}$, but not lower than the mean for Indopol ${ }^{\oplus}$. Levels of damage reduction as indicated by the width of gnawing measure were $96.8 \%$ for capsaicin and $35.6 \%$ for denatonium samples compared to Indopol ${ }^{\star}$.

We found significant effects for the volume of cable damage measure $\left(F_{3,20}=67.66 ; P=\right.$ 0.0024). Post hoc tests showed that only the mean for capsaicin was lower than the means for Indopol ${ }^{\oplus}$, Vexar ${ }^{\circledR}$, and denatonium benzoate. No other mean differences were detected. Levels of damage reduction as indicated by reduced volumes of gnawed cable material were $100.0 \%$ for capsaicin and $35.6 \%$ for denatonium cable samples compared to Indopol ${ }^{\star}$. Mean qualitative damage ratings after 7 days were $3.50 \pm 0.76$ (Indopol $\left.{ }^{\circledR}\right), 1.33 \pm 0.94$ (capsaicin), $2.83 \pm 1.34$ (denatonium benzoate), and $4.00 \pm$ 0.00 (Vexar ${ }^{(1)}$.

\section{DISCUSSION}

In Study 1, we used a simple surface-coating procedure for chemical repellent treatment applications. No significant repellent effects were observed. Means of all 5 damage measures for the 3 experimental treatments (capsicum, denatonium benzoate, Vexar ${ }^{\$}$ equaled or exceeded those obtained for the control treatment (Indopol $\left.{ }^{\circledR}\right)$. In Study 2, however, with the chemical repellents contained within a shrink-tube casing, there were strong significant repellent effects for capsaicin, and to a much lesser degree for denatonium benzoate. We also found that this general pattern of effects held for all quantitative measures: mass, depth, width, and volume of cable loss. All measures, in terms of mean values, were equal or higher when data for the Indopol ${ }^{\otimes}$ samples were compared to Vexar ${ }^{\circledR}$ samples.

At the same chemical concentration levels for Studies 1 and 2, we demonstrated a major change in repellent efficacy when a larger quantity of material (i.e., approximately $0.25 \mathrm{cc} / \mathrm{cm}$ cable length) was made available and contained within a flexible plastic heat-shrink tubing matrix. As the gophers attempted to chew topically applied repellents on standard cable samples, we noted via videotaped observations that they exhibited a great deal of tearing and biting on the outer portions of the cable coverings. The 
diastema spacing gives the gophers an anatomical advantage in that their incisors can be used to tear into material or soil without ingestion or oral contact (Ramey and McCann 1997). However, when a greater quantity of capsaicin is made available, the animals can generate more oral contact with a chemical repellent contained inside of a relatively tough plastic coating as they attempt to tear through with their incisors.

The Vexar plastic mesh material proved to be of no repellent value for cable protection against gopher damage. In both Studies 1 and 2 , there appeared to be more mean gnawing damage to $\operatorname{Vexar}^{\circledR}$ cable samples compared to all others including Indopol ${ }^{\circledR}$ (control) samples, but mean differences were not significant statistically. Nevertheless, it is possible that the plastic mesh material, at least in the aboveground laboratory cage-test situations, may be a potential attractant to cable gnawing by gophers. Greater sample sizes could be used to evaluate this potential in future research on cable gnawing. As plant protectors, however, some repellent effects have been reported when this material was used to protect tree seedlings from gopher damage (Anthony et al. 1978). However, these effects could have been due to gnawing by other species, or they could have reflected altered plant feeding patterns rather than repellent effects on gnawing per se. Gophers attempting to clear obstructions from their burrow systems for maintenance and expansion may be relatively unaffected in terms of any mechanical repellent effects of some physical barriers.

\section{MANAGEMENT IMPLICATIONS}

The method of applying chemical repellent agents to cable can determine repellent efficacy in gophers. Repellent studies on these and other species should include delivery mode (i.e., application procedures) as 1 of the factors to be examined, because other agents (e.g., easily registered natural products) are potentially available to alleviate or reduce economic problems and safety hazards posed by rodent gnawing activity. Capsaicin and possibly denatonium benzoate have been demonstrated, at least in these laboratory tests, to offer promise as agents that can significantly and reliably reduce cablegnawing damage by gophers.

Field-test evaluations of the encased cable repellent agents are planned, and results should provide a clearer view of efficacy when soil con- tact and moisture levels are uncontrolled. The Indopo ${ }^{\circledR}$ carrier material is used as a water repellent in cable applications and is available in a wide range of viscosities so that the loss of repellent due to incisor puncture and tearing on the encasement tubing can be controlled and reduced to some degree. To reduce material costs, alternate plastic encasement tubing will also be evaluated in future studies. The encased repellent method could have many useful applications where the presence of rodents near power or communications cables poses continual problems in terms of safety, health, and economic effects.

\section{ACKNOWLEDGMENTS}

We thank K. A. Hollenbeck for assistance in data analyses and construction of our figures, $\mathbf{R}$. M. Engeman for statistical consultation, G. W. Witmer and D. J. Elias for useful suggestions regarding manuscript revision, and $\mathrm{A}$. F. Dale and his staff for providing care and maintenance of the animals throughout these studies.

\section{LITERATURE CITED}

Anthony, R. M., V. G. Barnes, JR., And J. Evans. 1978. "Vexar" plastic netting to reduce pocket gopher depredations of conifer seedlings. Proceedings of the Vertebrate Pest Conference 8: 138-144.

Bryant, B. P. 1997. Peripheral trigeminal neural processes involved in repellency. Pages 19-27 in J. R. Mason, editor. Repellents in wildlife management: proceedings of the second Denver Wildlife Research Center special symposium. Colorado State University, Fort Collins, Colorado, USA.

Cogelia, N. J., G. K. LaVoie, and J. F. Glahn. 1976. Rodent biting pressure and chewing action and their effects on wire and cable sheath. International Wire and Cable Symposium 25:117-124.

Connolly, R. A., AND N. J. CogEliA. 1970. The gopher and buried cable. Bell Laboratories Record 48:98-103.

- , AND R. E. LANDSTrom. 1969. Gopher damage to buried cable materials. American Society for Testing and Materials, Materials Research and Standards 9:13-18.

Epple, G., H. Niblick, S. Lewis, D. L. Nolte, D. L. Campbell, AND J. R. MASON. 1996. Pine needle oil causes avoidance behavior in pocket gophers (Geomys bursarius). Journal of Chemical Ecology 22:1013-1025.

Fitzgerald, C. S., P. D. Curtis, M. E. Richmond, AND J. A. DUNN. 1997. Effectiveness of capsaicin as a repellent to birdseed consumption by gray squirrels. Pages 169-183 in J. R. Mason, editor. Repellents in wildlife management: proceedings of the second Denver Wildlife Research Center special symposium. Colorado State University, Fort Collins, Colorado, USA. 
HOWARD, W. E. 1953. Tests of pocket gophers gnawing electric cables. Journal of Wildlife Management 17:296-300.

MASON, J. R. 1998. Mammal repellents: options and considerations for development. Proceedings of the Vertebrate Pest Conference 18:325-329.

MCCANN, G. R. 1995. A method for evaluating cable resistance to damage by pocket gophers as adopted by the USDA/APHIS/ADC/DWRC. International Wire and Cable Symposium 44:604-606.

RAMEY, C. A., AND G. R. MCCANN. 1997. Evaluating cable resistance to pocket gopher damage-a review. Great Plains Wildlife Damage Control Workshop 13:107-113.

SAS INSTITUTE. 1992. SAS/ASSIST software: changes and enhancements. Version 6. SAS Institute, Cary, North Carolina, USA.
Sullivan, T. P., D. R. Crump, and D. S. Sullivan. 1988. The use of predator odor repellents to reduce feeding damage by herbivores: northern pocket gophers (Thomomys talpoides). Journal of Chemical Ecology 14:379-389.

WINER, B. J. 1971. Statistical principles in experimental design. Second edition. McGraw-Hill, New York, New York, USA.

Witmer, G. W., M. J. Pipas, and J. C. Bucher. 1998. Field tests of denatonium benzoate to reduce seedling damage by pocket gophers (Thomomys talpoides Rich.). Crop Protection 17:35-39.

Received 14 November 1998.

Accepted 26 April 1999.

Associate Editor: Rattner. 